\title{
Synthesis, characterization and electrochemical behavior of oxo-bridged (arylimido)[tris(3,5-dimethylpyrazolyl)borato] molybdenum(V) complexes
}

\author{
Isil Topaloglu-Sozuer ${ }^{\mathrm{a}, *}$, Alev Gunyar ${ }^{\mathrm{a}}$, Seckiner Dulger-Irdem ${ }^{\mathrm{a}}$, \\ Miguel Baya ${ }^{\mathrm{b}}$, Rinaldo Poli ${ }^{\mathrm{b}}$ \\ a Department of Chemistry, Faculty of Science, Izmir Institute of Technology, Gulbahce, Urla-35430, Izmir, Turkey \\ ${ }^{\mathrm{b}}$ Laboratoire de Chimie de Coordination, UPR CNRS 8241, 205 Route de Narbonne, 31077 Toulouse Cedex, France
}

Received 8 November 2004; received in revised form 5 May 2005; accepted 16 May 2005

\begin{abstract}
Reaction of the oxo-molybdenum(V) precursor $\left[\mathrm{MoTp}^{*}(\mathrm{O}) \mathrm{Cl}_{2}\right]\left[\mathrm{Tp}^{*}=\operatorname{hydrotris}(3,5\right.$-dimethyl-1-pyrazolyl)borate $]$ with $\mathrm{H}_{2} \mathrm{NC}_{6} \mathrm{H}_{4} \mathrm{R}-4$ ( $\mathrm{R}=\mathrm{OEt}$; OPr) in refluxing toluene in the presence of $\mathrm{Et}_{3} \mathrm{~N}$ afforded the binuclear oxo-bridged oxo(arylimido) molybdenum(V) complexes [Tp* $\mathrm{Mo}(\mathrm{O}) \mathrm{Cl}](\mu-\mathrm{O})\left[\mathrm{Tp} * \mathrm{Mo}\left(\mathrm{NC}_{6} \mathrm{H}_{4} \mathrm{OR}-4\right) \mathrm{Cl}\right]$. Surprisingly, a similar reaction between $\left[\mathrm{MoTp}^{*}(\mathrm{O}) \mathrm{Cl}_{2}\right]$ and $\mathrm{C}_{6} \mathrm{H}_{5} \mathrm{NH}_{2}$ yielded the previously reported compound [ $\left.\left\{\mathrm{MoTp}^{*}(\mathrm{O}) \mathrm{Cl}\right\}_{2}(\mu-\mathrm{O})\right]$ as the only product. The new compounds were characterized by microanalytical data, mass spectrometry, IR and ${ }^{1} \mathrm{H}$ NMR spectroscopy. Cyclic voltammetric studies of the new compounds, of the previously reported compounds $\left[\mathrm{Tp}^{*} \mathrm{Mo}(\mathrm{O}) \mathrm{Cl}\right](\mu-\mathrm{O})[\mathrm{Tp} * \mathrm{Mo}(\mathrm{NAr}) \mathrm{Cl}]\left(\mathrm{Ar}=\mathrm{C}_{6} \mathrm{H}_{4} \mathrm{OMe}-4, \mathrm{C}_{6} \mathrm{H}_{4} \mathrm{~F}-3\right.$, $\mathrm{C}_{6} \mathrm{H}_{4} \mathrm{Cl}-4, \mathrm{C}_{6} \mathrm{H}_{4} \mathrm{Br}-4$, and $\left.\mathrm{C}_{6} \mathrm{H}_{4} \mathrm{I}-3\right)$, and of $\left[\left\{\mathrm{MoTp}^{*}(\mathrm{O}) \mathrm{Cl}_{2}(\mu-\mathrm{O})\right]\right.$ revealed a reversible one-electron oxidation process that is little affected by the nature of the substituent on the aryl group, whereas it is greatly affected by replacement of the imido ligand with an oxo ligand. The $\left[\left\{\mathrm{MoTp}^{*}(\mathrm{O}) \mathrm{Cl}_{\}_{2}}(\mu-\mathrm{O})\right]\right.$ compound also shows a one-electron reduction process.
\end{abstract}

(C) 2005 Elsevier B.V. All rights reserved.

Keywords: Imido complexes; Molybdenum complexes; Oxo-bridged Mo(V) complexes; Oxo complexes; (Pyrazol)borato complexes; Electrochemistry

\section{Introduction}

Poly(pyrazolyl)borate ligands were first synthesized by Trofimenko [1] and have assumed an important role in modern coordination chemistry [2]. It has been shown that there are strong analogies between the behavior of metal complexes containing trispyrazolborato anions and those containing $\eta^{5}$-cyclopentadienyl ligands [1].

Molybdenum is a trace element and presents several oxidation states. Molybdenum is a relevant element

\footnotetext{
* Corresponding author. Tel.: +90 232 7507530; fax: +90 232 7507509.

E-mail address: isiltopaloglu@iyte.edu.tr (I. Topaloglu-Sozuer).
}

for the synthesis of many homogeneous and heterogenous catalysts. It is also essential in several enzymatic systems. One of the characteristics of the molybdenum chemistry is related to the easy conversion between its oxidation states and to the changes of coordination number, observed particularly between Mo(III), $\mathrm{Mo}(\mathrm{IV}), \mathrm{Mo}(\mathrm{V})$ and $\mathrm{Mo}(\mathrm{VI})$.

Oxo and imido ligands have been known to form commonly multiple bonds when attached to transition metal centers. There has been significant interest in the chemistry of the corresponding complexes. Of particular importance are the high-valent organo-imido and -oxo molybdenum derivatives which have been widely studied. Both the imido and oxo groups lead to stabilization 
of high formal oxidation states. A large number of imido compounds are known for the majority of the transition metals in various oxidation states, although highvalent centers in which the metal has a $\mathrm{d}^{0}-\mathrm{d}^{2}$ electronic configuration are particularly stable [3]. Organo-imido complexes of $\mathrm{Mo}(\mathrm{V})$ and $\mathrm{Mo}(\mathrm{VI})$ can be prepared by a wide range of methods that often make use of organic compounds as the imido transfer reagent $[3,4]$. There are several molybdenum imido compounds [5-10] and a number of related mixed terminal oxo-imido compounds have previously been reported, for instance [MoTp*(O)Cl(NR)] ( $\mathrm{R}=4$-tolyl and $\left.\mathrm{C}_{6} \mathrm{H}_{4} \mathrm{NMe}_{2}-4\right)$ [11], [ $\mathrm{MoCl}_{2}(\mathrm{Nmes})(\mathrm{O})($ bipy)$) \quad($ mes $=2,4,6$-trimethylphenyl) [12] and $\left[\mathrm{TpMo}\left(\mathrm{CH}_{2} \mathrm{C}(\mathrm{Me})(2) \mathrm{Ph}\right)(\mathrm{NAr})(\mathrm{O})\right]$ $\left(\mathrm{Ar}=2,6-i-\mathrm{Pr}-2-\mathrm{C}_{6} \mathrm{H}_{3}, \quad \mathrm{Ph}=\mathrm{C}_{6} \mathrm{H}_{5}\right) \quad$ [13], but limited information is available for transition metal compounds containing both imido and hydrotris(pyrazolyl)borate type ligands [11,14-21]. Although a number of systems involving $\mu$-ligation in the presence of terminal imido groups have previously been reported [22-26], the chemistry of compounds having both arylimido and $\mu$-oxo group in the presence of tris(pyrazolyl)borate co-ligand has not been studied in detail.

We have recently described the synthesis and spectroscopic characterization of a family of oxo-bridged oxo(arylimido)molybdenum(V) complexes having the general formula $[\mathrm{Tp} * \mathrm{Mo}(\mathrm{O}) \mathrm{Cl}](\mu-\mathrm{O})[\mathrm{Tp} * \mathrm{Mo}(\mathrm{NAr}) \mathrm{Cl}]$ $\left[\mathrm{Ar}=\mathrm{C}_{6} \mathrm{H}_{4} \mathrm{X}-4\left(\mathrm{X}=\mathrm{OMe}, \mathbf{1}, \mathrm{NO}_{2}, 2\right.\right.$ [27]; $\mathrm{Cl}, \mathbf{3}, \mathrm{Br}, \mathbf{4}$ [28]) or $\mathrm{C}_{6} \mathrm{H}_{4} \mathrm{X}-3(\mathrm{X}=\mathrm{F}, \mathbf{5}, \mathrm{I}, \mathbf{6}$ [29]) by the reaction of $\left[\mathrm{MoTp}^{*}(\mathrm{O}) \mathrm{Cl}_{2}\right]$ with the corresponding $\mathrm{H}_{2} \mathrm{NAr}$ in refluxing toluene. These are the first examples of molybdenum compounds containing both an arylimido and a $\mu$-oxo group in the presence of a tris(pyrazolyl)borate co-ligand. Single crystal X-ray crystallographic characterizations were carried out for compounds $\mathbf{1}, \mathbf{4}, \mathbf{5}$ and 6. All these structural determinations revealed the same molecular scaffold, which consists of a linear Mo-O-Mo bridge and an essentially linear arylimido group, as shown schematically in Scheme 1. The $\mathrm{M}-\mathrm{N}-\mathrm{Ar}$ linearity and the Mo-N distance suggest significant participation of the $\mathrm{N}$ lone pair in bonding, providing an effective triple bond $(\sigma+2 \pi)$ character to the interaction with the imido ligand (like for the isolobal interaction with the terminal oxo ligand).

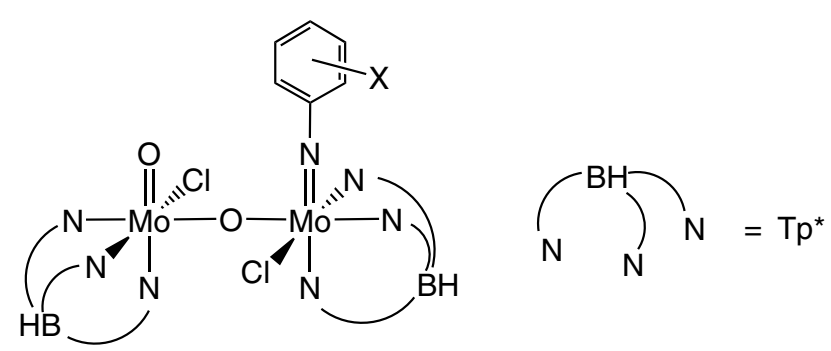

Scheme 1.
The structure shows, in some cases, the oxo and imido ligands on the same side of the molecule (syn), in which case the $\mathrm{Cl}$ ligands occupy opposite positions (anti), as in Scheme 1. However, a different conformation, where the two $\mathrm{Cl}$ ligands are syn and the oxo and imido ligands are anti has also been observed in other cases. For two compounds (4 and 5), both conformations have been observed in different crystals. The ${ }^{1} \mathrm{H}$ NMR properties of the entire family of compounds are consistent with the asymmetric structure (e.g., 12 different Me resonances and 6 different pyrazolyl methyl resonances are observed in the expected relative intensities for the 6 inequivalent pyrazolyl rings). Thus, the same structure is assumed for all the compounds for which a structural determination could not be carried out.

In this paper, we report the preparation and spectroscopic characterization of compounds $\left[\mathrm{Tp}^{*} \mathrm{Mo}(\mathrm{O}) \mathrm{Cl}\right](\mu-$ $\mathrm{O})\left[\mathrm{Tp}^{*} \mathrm{Mo}\left(\mathrm{NC}_{6} \mathrm{H}_{4} \mathrm{X}-4\right) \mathrm{Cl}\right]\left(\mathrm{R}=\mathrm{OEt}, 7\right.$; $\left.\mathrm{OPr}^{n}, 8\right)$ as an extension of the previously reported compounds. This paper also presents the results of electrochemical studies of the entire family of compounds (1-8) and a comparison with the electrochemical behavior of the related compound $\left[\mathrm{Tp}^{*} \mathrm{Mo}(\mathrm{O}) \mathrm{Cl}\right]_{2}(\mu-\mathrm{O})[30,31]$.

\section{Experimental}

\subsection{General methods}

All preparations and manipulations were carried out with Schlenk techniques under an oxygen-free dinitrogen atmosphere. All glassware was oven-dried at $120^{\circ} \mathrm{C}$. Solvents were dried by standard procedures, distilled and kept under dinitrogen over $4 \AA$ molecular sieves.

The starting material $\left[\mathrm{MoTp} *(\mathrm{O}) \mathrm{Cl}_{2}\right]$ was prepared according to Enemark's published method [32].

The solid state infrared spectra were recorded on a Magna IR spectrophotometer as pressed $\mathrm{KBr}$ disks. The solution IR spectra in the low-energy region were recorded in $\mathrm{CH}_{2} \mathrm{Cl}_{2}$ solutions on a Perkin-Elmer GX spectrometer. ${ }^{1} \mathrm{H}$ NMR spectra were recorded in $\mathrm{CDCl}_{3}$ on $400 \mathrm{MHz}$ High Performance Digital FT NMR at TUBITAK (Research Council of Turkey) and on a Bruker AC250 FT NMR spectrometer at the LCC Toulouse. Mass spectra analyses were performed on a Joel AX505 FAB device using Xe at $3 \mathrm{kV}$ as a positive ion and a matrix $m$-NBA (meta-nitrobenzyl alcohol). Cyclic voltammograms were recorded with an EG \& G 362 potentiostat connected to a Macintosh computer through MacLab hardware/sofware. The electrochemical cell was fitted with an SCE reference electrode, a platinum disk working electrode and a platinum wire counter-electrode. $\left[\mathrm{Bu}_{4} \mathrm{~N}\right] \mathrm{PF}_{6}(\mathrm{ca} .0 .1 \mathrm{M})$ was used as the supporting electrolyte in $\mathrm{CH}_{2} \mathrm{Cl}_{2}$. All potentials are reported relative to the ferrocene standard, which was 
added to each solution and measured at the end of the experiments. The potential of the ferrocene standard under our working conditions is $0.465 \mathrm{~V}$. Elemental analyses were carried out using a LECO CHNS 932 instrument.

\subsection{Preparation of $\left[\mathrm{Tp}^{*} \mathrm{Mo}(\mathrm{O}) \mathrm{Cl}\right](\mu-\mathrm{O})$ $\left[\mathrm{Tp}^{*} \mathrm{Mo}\left(\mathrm{NC}_{6} \mathrm{H}_{4} \mathrm{OEt}-4\right) \mathrm{Cl}\right]$ (7)}

A mixture of $\left[\mathrm{MoTp}^{*}(\mathrm{O}) \mathrm{Cl}_{2}\right](0.2 \mathrm{~g}, 0.40 \mathrm{mmol})$, $\mathrm{H}_{2} \mathrm{NC}_{6} \mathrm{H}_{4} \mathrm{OEt}-4(0.051 \mathrm{~g}, 0.20 \mathrm{mmol})$ and dry $\mathrm{Et}_{3} \mathrm{~N}$ $\left(0.6 \mathrm{~cm}^{3}, 0.42 \mathrm{mmol}\right)$ in dry toluene $\left(20 \mathrm{~cm}^{3}\right)$ was heated to reflux with stirring under $\mathrm{N}_{2}$ for $21 \mathrm{~h}$. The mixture was cooled, filtered and evaporated to dryness. The residue was dissolved in dichloromethane and chromatographed on silica gel using $\mathrm{CH}_{2} \mathrm{Cl}_{2} / n$-hexane $(9: 1$, v/v) as eluant. The dark-red fraction was collected and crystallized from $\mathrm{CH}_{2} \mathrm{Cl}_{2} / n$-hexane to afford the compound $[\mathrm{Tp} * \mathrm{Mo}(\mathrm{O}) \mathrm{Cl}](\mu-\mathrm{O})\left[\mathrm{Tp} * \mathrm{Mo}\left(\mathrm{NC}_{6} \mathrm{H}_{4} \mathrm{OEt}-4\right) \mathrm{Cl}\right] \quad(0.09 \mathrm{~g}$, $45 \%)$.

\subsection{Preparation of $\left[\mathrm{Tp}^{*} \mathrm{Mo}(\mathrm{O}) \mathrm{Cl}\right](\mu-\mathrm{O})$ $\left[\mathrm{Tp}^{*} \mathrm{Mo}\left(\mathrm{NC}_{6} \mathrm{H}_{4} \mathrm{OPr}^{n}-4\right) \mathrm{Cl}\right](\boldsymbol{8})$}

A mixture of $\left[\mathrm{MoTp}^{*}(\mathrm{O}) \mathrm{Cl}_{2}\right](0.2 \mathrm{~g}, 0.40 \mathrm{mmol})$, $\mathrm{H}_{2} \mathrm{NC}_{6} \mathrm{H}_{4} \mathrm{OPr}^{n}-4(0.06 \mathrm{~g}, 0.20 \mathrm{mmol})$ and dry $\mathrm{Et}_{3} \mathrm{~N}$ $\left(0.6 \mathrm{~cm}^{3}, 0.42 \mathrm{mmol}\right)$ in dry toluene $\left(20 \mathrm{~cm}^{3}\right)$ was heated to reflux with stirring under $\mathrm{N}_{2}$ for $19 \mathrm{~h}$. The reaction was followed by TLC using the procedure described above for (7) to afford the compound $[\mathrm{Tp} * \mathrm{Mo}(\mathrm{O}) \mathrm{Cl}](\mu-\mathrm{O})\left[\mathrm{Tp} * \mathrm{Mo}\left(\mathrm{NC}_{6} \mathrm{H}_{4} \mathrm{OPr}^{n}-4\right) \mathrm{Cl}\right]$ as red microcrystals $(0.075 \mathrm{~g}, 38 \%)$.

\section{Results and discussion}

\subsection{Synthetic aspects}

The new compounds were prepared in the same general way as the previously reported ones (1-6) by reaction of $\left[\mathrm{Tp}^{*} \mathrm{Mo}(\mathrm{O}) \mathrm{Cl}_{2}\right]$ with the appropriate aniline in refluxing toluene, in the presence of $\mathrm{Et}_{3} \mathrm{~N}$, by double deprotonation of the corresponding aniline. Thus, the reaction of the oxo-molybdenum $(\mathrm{V})$ precursor, [MoTp*(O) $\mathrm{Cl}_{2}$ ], with $\mathrm{H}_{2} \mathrm{NC}_{6} \mathrm{H}_{4} \mathrm{X}-4$ (X = OEt, OPr) afforded compounds $[\mathrm{Tp} * \mathrm{Mo}(\mathrm{O}) \mathrm{Cl}](\mu-\mathrm{O})\left[\mathrm{Tp} * \mathrm{Mo}\left(\mathrm{NC}_{6} \mathrm{H}_{4} \mathrm{X}-\right.\right.$ 4)Cl] (X = OEt, 7; OPr, 8) in moderate yields according to the stoichiometry of Eq. (1)

$$
\begin{aligned}
& 2 \mathrm{Tp}^{*} \mathrm{Mo}(\mathrm{O}) \mathrm{Cl}_{2}+\mathrm{H}_{2} \mathrm{NC}_{6} \mathrm{H}_{4} \mathrm{X}-4+2 \mathrm{Et}_{3} \mathrm{~N} \\
& \stackrel{\Delta}{\stackrel{\Delta}{\rightarrow}}\left[\mathrm{Tp}^{*} \mathrm{Mo}(\mathrm{O}) \mathrm{Cl}\right](\mu-\mathrm{O})\left[\mathrm{Tp}^{*} \mathrm{Mo}\left(\mathrm{NC}_{6} \mathrm{H}_{4} \mathrm{X}-4\right) \mathrm{Cl}\right] \\
& \quad+2 \mathrm{Et}_{3} \mathrm{NH}^{+} \mathrm{Cl}^{-}\left(\mathrm{X}=\mathrm{OEt}, 7 ; \mathrm{OPr}^{n}, \mathbf{8}\right)
\end{aligned}
$$

In these reactions, the dinuclear oxo-imido $\mathrm{Mo}(\mathrm{V})$ compounds were the main products and the first ones to migrate through a silica column with elution by $\mathrm{CH}_{2} \mathrm{Cl}_{2} /$ $n$-hexane $(9: 1, \mathrm{v} / \mathrm{v})$; traces of the previously reported compound, [\{MoTp*(O)Cl $\left.\}_{2}(\mu-\mathrm{O})\right](9)$, were eluted after 7 and $\mathbf{8}$. Surprisingly, 9 is the major product for the reaction of $\left[\mathrm{MoTp}^{*}(\mathrm{O}) \mathrm{Cl}_{2}\right]$ with aniline under identical conditions. There were other weak bands of other products, but 7, 8 and 9 could be obtained in a pure state and in sufficient amounts to allow their spectroscopic characterization. Compounds $\mathbf{7}$ and $\mathbf{8}$ are soluble in common organic solvents and stable in moist air. They can be easily separated from the reaction mixture by crystallization from a dichloromethane/hexane mixture (1:4). Microanalytical data were in accord with the proposed formulations. Characterization data for the new compounds are collected in Table 1.

\subsection{Mechanistic considerations}

A remarkable feature of the reaction, which has already been discussed [27], is the fact that a dinuclear compound containing only one imido group per two Mo atoms is obtained, in an essentially selective manner, even though an excess amount of the aniline reagent was used in most cases. An additional, new consideration is derived from a comparison of all structures determined so far [27-29]. This shows that the molecule systematically adopts the same diastereomeric configuration. In fact, since both metal centers in the product are chiral and chemically inequivalent, two enantiomeric pairs of diastereomers are possible in principle, depending on the absolute configuration of each metal. This unusual stereoselectivity forces us to consider the mechanism of formation of the compound in greater detail.

The first step of the process, which may be equilibrated, is likely to be the addition of the aniline to the $\mathrm{Mo}(\mathrm{V})$ center in compound $\mathrm{Tp} * \mathrm{Mo}(\mathrm{O}) \mathrm{Cl}_{2}$, since this has an unsaturated 15-electron configuration (17-electron if we consider additional $\pi$ donation from the oxo ligand to yield a Mo-O triple $(\sigma+2 \pi)$ bond). Elimination of $\mathrm{HCl}$, assisted by $\mathrm{NEt}_{3}$, may yield a $\mathrm{Tp} * \mathrm{Mo}(\mathrm{O})(\mathrm{NHAr}) \mathrm{Cl}$ intermediate. Because of the

Table 1

Characterization data for compounds $\mathbf{7}$ and $\mathbf{8}$

\begin{tabular}{llllll}
\hline Compound & Color & Yield (\%) & \multicolumn{2}{l}{ Microanalytical data (Calc.) (\%) } & FAB-MS \\
\cline { 5 - 6 } & & & C & H & N \\
\hline $\mathbf{7}$ & dark red & 50 & $44.58(45.01)$ & $5.21(5.52)$ & $17.78(18.22)$ \\
$\mathbf{8}$ & brown & 55 & $45.10(45.44)$ & $5.23(5.48)$ & $17.53(17.96)$ \\
\hline
\end{tabular}


increased electron density (an amido ligand is a stronger $\sigma$ donor than a chloride), this compound may now be capable of attacking the metal center of a second $\mathrm{Tp} * \mathrm{Mo}(\mathrm{O}) \mathrm{Cl}_{2}$ molecule, as shown in Scheme 2, whereas attack by the same $\mathrm{Tp} * \mathrm{Mo}(\mathrm{O}) \mathrm{Cl}_{2}$ (i.e., dimerization) does not spontaneously occur. The dinuclear product is then stabilized thermodynamically by the elimination of a chlorine ligand from the oxo-molybdenum moiety and a proton from the amidomolybdenum moiety, the latter one generating the new imido ligand. Thus, the selective formation of a mixed oxo-imido dinuclear species arises from the greater Lewis basicity of the amidosubstituted intermediate and the greater Lewis acidity of the dichloride starting complex. The reason why excess aniline does not further attack the product, to yield a possible bis-amido derivative, may be related to the greater electron richness (lower electrophilicity) of the Mo centers in the products, because of the replacement of a chloride ligand by the more $\pi$-donating $\mu$-oxo ligand. The diastereoselectivity of the reaction means that the absolute configuration of the $\mathrm{Tp} * \mathrm{Mo}(\mathrm{O})(\mathrm{NHAr}) \mathrm{Cl}$ intermediate must exert a $100 \%$ induction on the absolute configuration of the second metal. If the detailed mechanism is indeed as shown in Scheme 2, this selectivity requires that the first dinuclear intermediate undergoes a stereoselective chloride ion elimination. Other mechanistic pathways are of course possible. The specific stereoelectronic reason for this perfect stereochemical control remains obscure. However, it seems possible that the molecule may be pre-organized by the establishment of a $\mathrm{Mo}=\mathrm{N}(\mathrm{Ar})-\mathrm{H} \cdots \mathrm{O}=$ Mo hydrogen bond, before the chloride ion elimination.

The formation of the dinuclear $\mu$-oxomolybdenum $(\mathrm{V})$ compound, [\{MoTp* $\left.(\mathrm{O}) \mathrm{Cl}\}_{2}(\mu-\mathrm{O})\right]$, from $\left[\mathrm{MoTp}^{*}(\mathrm{O}) \mathrm{Cl}_{2}\right]$ and $\mathrm{C}_{6} \mathrm{H}_{5} \mathrm{NH}_{2}$, and also as a by-product of the reactions with the substituted anilines, is also of interest. This compound was previously prepared by McCleverty et al. [30] by the reaction of [MoTp* $(\mathrm{O})_{2} \mathrm{Cl}$ ] and $\mathrm{PPh}_{3}$ in wet toluene containing $\approx 0.03 \%$ water. Millar et al. [31] prepared the same compound serendipitously by treatment of 1,3-dimethoxy-para-tert-butylcalix[4]arene and $\left[\mathrm{MoTp}^{*}(\mathrm{O}) \mathrm{Cl}_{2}\right]$ in refluxing toluene. The synthesis was also successful in the absence of calixarene, therefore, it was suggested that the complex formed because of the presence of adventitious water, probably originating from $\mathrm{Et}_{3} \mathrm{~N}$. Thus, it is safe to conclude that the formation of $\mathbf{9}$ in our reactions could also result from the presence of adventitious water originating from toluene or $\mathrm{Et}_{3} \mathrm{~N}$ or the aniline.

\subsection{Spectroscopic studies}

The IR and ${ }^{1} \mathrm{H}$ NMR data obtained for $\mathbf{7}$ and $\mathbf{8}$ are very similar to those of 1-6. This strongly suggests that all these complexes have the same structure (Scheme 1). The IR data are collected in Table 2. Both compounds exhibit the expected absorptions due to the Tp* ligand (ca. $2500 \mathrm{~cm}^{-1}$ due to $v_{(\mathrm{BH})}$ and ca. $1400 \mathrm{~cm}^{-1}$ associated with the pyrazolyl ring). They possess bands at ca. $960 \mathrm{~cm}^{-1}$, characteristic of the terminal $\mathrm{Mo}=\mathrm{O}$ unit for $\mathrm{Mo}(\mathrm{V})$ complexes. Both compounds also exhibited peaks at $1212 \mathrm{~cm}^{-1}$ which could be attributed to the presence of a $\mathrm{Mo}=\mathrm{N}$ moiety in these species. For comparison, the previously reported compounds 1-6 exhibited a strong peak at ca. $1205 \mathrm{~cm}^{-1}$, which was assigned as $v_{(\mathrm{Mo}=\mathrm{N})}$ on the basis of the data suggested

Table 2

IR data $\left(4000-600 \mathrm{~cm}^{-1}\right)$ for complexes 7 and $\mathbf{8}$

\begin{tabular}{llllll}
\hline Compound & $v_{(\mathrm{B}-\mathrm{H})}{ }^{\mathrm{a}}$ & $v_{(\mathrm{Mo}=\mathrm{O})}{ }^{\mathrm{a}}$ & $v_{(\mathrm{C}-\mathrm{H})}{ }^{\mathrm{a}}$ & $v_{(\mathrm{Mo} \equiv \mathrm{N})}{ }^{\mathrm{a}}$ & $v_{(\mathrm{Mo}-\mathrm{Cl})}{ }^{\mathrm{b}}$ \\
\hline $\mathbf{7}$ & 2547 & 949 & 1413 & 1212 & 426.5 \\
$\mathbf{8}$ & 2547 & 961 & 1410 & 1212 & 426.5 \\
\hline
\end{tabular}

${ }^{\text {a }}$ Solid state spectra in $\mathrm{KBr}$ disks.

b In $\mathrm{CH}_{2} \mathrm{Cl}_{2}$ solution. The corresponding $v(\mathrm{Mo}-\mathrm{Cl})$ band for compound 1 is observed at $426 \mathrm{~cm}^{-1}$.

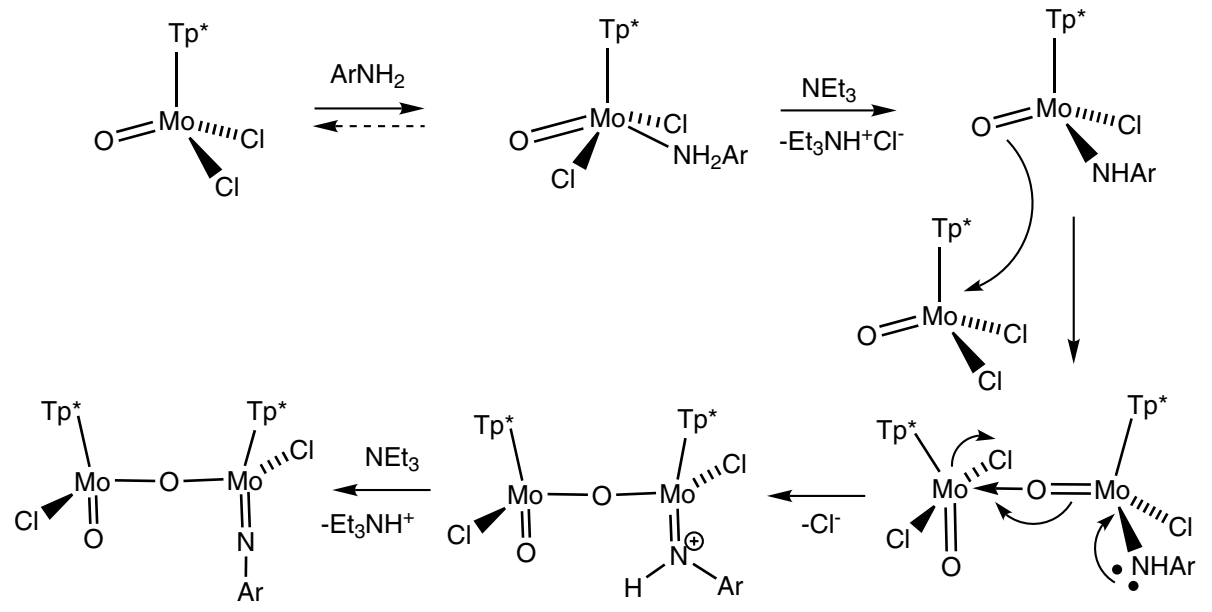

Scheme 2 . 
by Dehnicke and Strähle [33] and McCleverty and coworkers [11]. Further evidence for the existence of $\mathrm{Mo}=\mathrm{N}$ linkages is the fact that, in each case, the symmetric and asymmetric $\mathrm{NH}_{2}$ stretching modes of the free ligand (ca. 3370 and $3450 \mathrm{~cm}^{-1}$ ) have completely disappeared. Low-energy spectra were also measured for these compounds, as well as for the methoxy analog (compound 1) in the far IR region, where metal-halogen stretching vibrations are found. All three compounds show a very similar spectral patterns (e.g., see the spectra of compounds 7 and $\mathbf{8}$ in Fig. 1). According to the literature, terminal $\mathrm{M}-\mathrm{Cl}$ stretching vibrations are usually found in the $400-200 \mathrm{~cm}^{-1}$, the frequency being higher when the metal has a higher oxidation state. IR-active $\mathrm{Mo}-\mathrm{Cl}$ vibrations are reported at $308 \mathrm{~cm}^{-1}$ for $\left[\mathrm{MoCl}_{6}\right]^{2-}, 327 \mathrm{~cm}^{-1}$ for $\left[\mathrm{MoCl}_{6}\right]^{-}$and $418 \mathrm{~cm}^{-1}$ for $\mathrm{MoCl}_{5}$ [34]. Compound $\mathrm{MoCl}_{6}$ is nonexistent. It seems likely, therefore, that the $\mathrm{Mo}-\mathrm{Cl}$ bonds give rise to the sharper stretching vibration at ca. $426 \mathrm{~cm}^{-1}$. It is unlikely that the two $\mathrm{Mo}-\mathrm{Cl}$ bonds are strongly coupled to each other, given their relative distance. It seems, therefore, that the two $\mathrm{Mo}-\mathrm{Cl}$ vibrations are probably overlapping in the observed band at $426 \mathrm{~cm}^{-1}$.

The ${ }^{1} \mathrm{H}$ NMR data (Table 3) of the complexes are consistent with their formulation and are similar to those of the previously reported compounds 1-6. The two inequivalent $\mathrm{Tp}^{*}$ ligands give rise to two different groups of signals. For compound 7, six independent singlets in the region from 5.34 to $6.74 \mathrm{ppm}$, corresponding to the pyrazolyl $\mathrm{C}-\mathrm{H}$ protons, and twelve singlets in the region from 1.00 to $3.20 \mathrm{ppm}$, corresponding to the methyl protons, are observed. For compound $\mathbf{8}$, a very similar pattern is observed (see Table 3 ) except that a few of the pyrazolyl methyl resonances are broadened, perhaps by a rapid equilibrium with a $\kappa^{2}$ (bidentate) form of the Tp* ligand. These observations unambiguously confirm the absence of any symmetry element relating the two Mo centers in the reported complexes.

The ${ }^{1} \mathrm{H}$ NMR spectra of $\mathbf{7}$ and $\mathbf{8}$ do not display any signals due to the NH protons as expected, further sup-

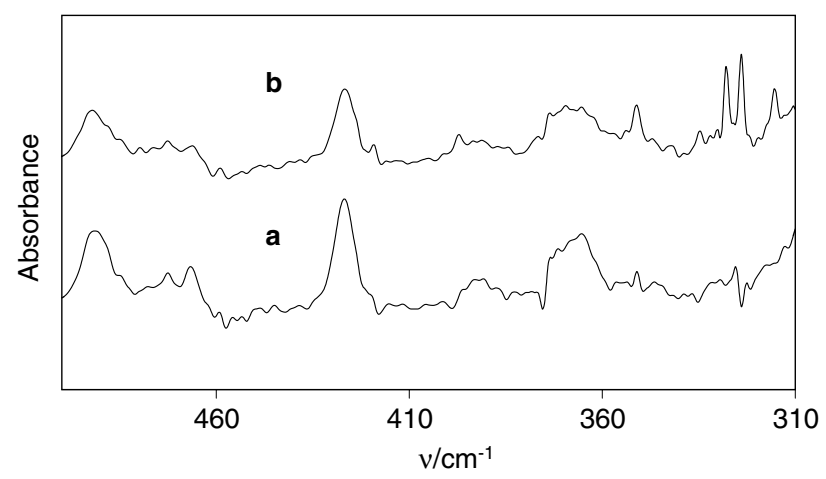

Fig. 1. Low-energy infrared spectra of compounds [Tp* $\mathrm{Mo}(\mathrm{O}) \mathrm{Cl}]$ $(\mu-\mathrm{O})\left[\mathrm{Tp} * \mathrm{Mo}\left(\mathrm{NC}_{6} \mathrm{H}_{4} \mathrm{OR}-4\right) \mathrm{Cl}\right]$ in $\mathrm{CH}_{2} \mathrm{Cl}_{2}$ solution: (a) $\mathrm{R}=\mathrm{Et}$; (b) $\mathrm{R}=n$-Pr.
Table 3

${ }^{1} \mathrm{H}$ NMR data for compounds 7 and $8\left(400 \mathrm{MHz}, 293 \mathrm{~K}, \mathrm{CDCl}_{3}\right)$

\begin{tabular}{lll}
\hline \multicolumn{1}{l}{$\delta /$ ppm (multiplicity, $J / \mathrm{Hz})$} & Assignment \\
\hline 7 & $\mathbf{8}$ & \\
\hline $7.48(\mathrm{~d}, 9)$ & $7.51(\mathrm{~d}, 9)$ & $\mathrm{NC}_{6} \mathrm{H}_{4} \mathrm{OR}$ \\
$6.74(\mathrm{~d}, 9)$ & $6.75(\mathrm{~d}, 9)$ & $\mathrm{Ne}_{6} \mathrm{H}_{4} \mathrm{OR}$ \\
$6.02(\mathrm{~s})$ & $6.02(\mathrm{~s})$ & $\mathrm{Me}_{2} \mathrm{C}_{3} H \mathrm{H}_{2}$ \\
$5.92(\mathrm{~s})$ & $5.92(\mathrm{~s})$ & $\mathrm{Me}_{2} \mathrm{C}_{3} \mathrm{HN}_{2}$ \\
$5.79(\mathrm{~s})$ & $5.80(\mathrm{~s})$ & $\mathrm{Me}_{2} \mathrm{C}_{3} H \mathrm{H}_{2}$ \\
$5.77(\mathrm{~s})$ & $5.79(\mathrm{~s})$ & $\mathrm{Me}_{2} \mathrm{C}_{3} \mathrm{HN}_{2}$ \\
$5.40(\mathrm{~s})$ & $5.40(\mathrm{~s})$ & $\mathrm{Me}_{2} \mathrm{C}_{3} \mathrm{HN}_{2}$ \\
$5.34(\mathrm{~s})$ & $5.35(\mathrm{~s})$ & $\mathrm{Me}_{2} \mathrm{C}_{3} \mathrm{HN}_{2}$ \\
$3.17(\mathrm{~s})$ & $3.19(\mathrm{~s}, \mathrm{br})$ & $\mathrm{Me}_{2} \mathrm{C}_{3} \mathrm{HN}_{2}$ \\
$2.75(\mathrm{~s})$ & $2.72(\mathrm{~s}, \mathrm{br})$ & $\mathrm{Me}_{2} \mathrm{C}_{3} \mathrm{HN}_{2}$ \\
$2.69(\mathrm{~s})$ & $2.70(\mathrm{~s})$ & $\mathrm{Me}_{2} \mathrm{C}_{3} \mathrm{HN}_{2}$ \\
$2.46(\mathrm{~s})$ & & $\mathrm{Me}_{2} \mathrm{C}_{3} \mathrm{HN}_{2}$ \\
$2.44(\mathrm{~s})$ & $2.48(\mathrm{~s}, \mathrm{br})^{\mathrm{a}}$ & $\mathrm{Me}_{2} \mathrm{C}_{3} \mathrm{HN}_{2}$ \\
$2.41(\mathrm{~s})$ & & $\mathrm{Me}_{2} \mathrm{C}_{3} \mathrm{HN}_{2}$ \\
$2.34(\mathrm{~s})$ & $2.36(\mathrm{~s})$ & $\mathrm{Me}_{2} \mathrm{C}_{3} \mathrm{HN}_{2}$ \\
$2.33(\mathrm{~s})$ & $2.33(\mathrm{~s})$ & $\mathrm{Me}_{2} \mathrm{C}_{3} \mathrm{HN}_{2}$ \\
$2.29(\mathrm{~s})$ & $2.29(\mathrm{~s})$ & $\mathrm{Me}_{2} \mathrm{C}_{3} \mathrm{HN}_{2}$ \\
$1.25(\mathrm{~s})$ & $1.55(\mathrm{~s})$ & $\mathrm{Me}_{2} \mathrm{C}_{3} \mathrm{HN}_{2}$ \\
$1.11(\mathrm{~s})$ & $1.11(\mathrm{~s})$ & $\mathrm{Me}_{2} \mathrm{C}_{3} \mathrm{HN}_{2}$ \\
$1.03(\mathrm{~s})$ & $1.03(\mathrm{~s})$ & $\mathrm{Me}_{2} \mathrm{C}_{3} \mathrm{HN}_{2}$ \\
$4.04(\mathrm{q}, 7)$ & $3.93(\mathrm{t}, 7)$ & $\mathrm{OCH}_{2}$ \\
& $1.80(\mathrm{pseudo} \mathrm{sext,} \mathrm{7)}$ & $\mathrm{OCH}_{2} \mathrm{CH}_{2} \mathrm{CH}_{3}$ \\
$1.41(\mathrm{t}, 7)$ & $1.03(\mathrm{t}, 7)$ & $\mathrm{CH}_{2} \mathrm{CH}_{3}$ \\
\hline
\end{tabular}

${ }^{\text {a }}$ Higher intensity than $3 \mathrm{H}$.

porting the existence of an imido ligand. The four $\mathrm{C}_{6} \mathrm{H}_{4}$ protons are clearly split into two sets of two (implying the equivalence of $\mathrm{H}^{2}$ with $\mathrm{H}^{6}$, and $\mathrm{H}^{3}$ with $\mathrm{H}^{5}$, due to the free rotation of the phenyl ring with respect to the metal core). The resonances for the ethoxy group in 7 and the propoxy group in $\mathbf{8}$ are all observed at the expected positions, confirming the attachment of the $\mathrm{R}$ (OEt, OPr) group to the $\mathrm{C}_{6} \mathrm{H}_{4}$ ring. The molecular ion peaks determined from the mass spectrometric data are also in good agreement with the suggested formulae (Table 1).

\subsection{Electrochemical studies}

The new compounds $\mathbf{7}$ and $\mathbf{8}$ have been studied electrochemically by cyclic voltammetry in $\mathrm{CH}_{2} \mathrm{Cl}_{2}$, together with their analogous derivatives 1-6, and with the related symmetric oxo complex $\left[\mathrm{Tp}^{*} \mathrm{Mo}(\mathrm{O}) \mathrm{Cl}\right]_{2}(\mu-\mathrm{O})$. All the mixed oxo-imido compounds display a reversible one-electron oxidation wave and no reduction process down to the potential at which the $\mathrm{CH}_{2} \mathrm{Cl}_{2}$ starts to discharge. The oxidation process occurs at a potential in a very narrow range for the whole family of compounds 1-8, i.e., it is little dependent on the nature of the substituent on the imido aryl group, see Table 4 . The peak-topeak separation is always close to the theoretical value of $60 \mathrm{mV}$ for a one-electron process. It is smaller, in many cases, than the corresponding value measured for the ferrocene wave (because of the greater concentration used for the latter), after adding this compound to 
Table 4

$E_{1 / 2}(\mathrm{~V})$ and $\Delta E_{\mathrm{p}}(\mathrm{mV})$ for the reversible oxidation process of compounds $[\mathrm{Tp} * \mathrm{Mo}(\mathrm{O}) \mathrm{Cl}](\mu-\mathrm{O})[\mathrm{Tp} * \mathrm{Mo}(\mathrm{NAr}) \mathrm{Cl}]$ (solvent $=\mathrm{CH}_{2} \mathrm{Cl}_{2}$; supporting electrolyte: $\mathrm{Bu}_{4}^{n} \mathrm{NPF}_{6}$ )

\begin{tabular}{lllll}
\hline Compound & $\mathrm{Ar}$ & $E_{1 / 2}(\mathrm{~V})$ & $\Delta E_{\mathrm{p}}(\mathrm{mV})$ & $\begin{array}{l}\Delta E_{\mathrm{p}}(\mathrm{mV}) \text { of } \\
\mathrm{Cp}_{2} \mathrm{Fe}\end{array}$ \\
\hline $\mathbf{1}$ & $\mathrm{C}_{6} \mathrm{H}_{4} \mathrm{OMe}-4$ & +0.06 & 73 & 131 \\
$\mathbf{7}$ & $\mathrm{C}_{6} \mathrm{H}_{4} \mathrm{OEt}-4$ & +0.06 & 71 & 126 \\
$\mathbf{8}$ & $\mathrm{C}_{6} \mathrm{H}_{4} \mathrm{OPr}^{n}-4$ & +0.06 & 81 & 133 \\
$\mathbf{5}$ & $\mathrm{C}_{6} \mathrm{H}_{4} \mathrm{~F}-3$ & +0.17 & 80 & 195 \\
$\mathbf{3}$ & $\mathrm{C}_{6} \mathrm{H}_{4} \mathrm{Cl}-4$ & +0.14 & 88 & 130 \\
$\mathbf{4}$ & $\mathrm{C}_{6} \mathrm{H}_{4} \mathrm{Br}-4$ & +0.19 & 79 & 84 \\
$\mathbf{6}$ & $\mathrm{C}_{6} \mathrm{H}_{4} \mathrm{I}-3$ & +0.16 & 96 & 122 \\
\hline
\end{tabular}

the same solutions. This is a good indication that the observed oxidations correspond indeed to one-electron processes.

The one-electron nature of the process was confirmed by three additional observations: more accurate studies of compound $\mathbf{3}$ showed the existence of a second oxidation wave at a very positive potential, quite close to the solvent discharge (see Fig. 2), with approximately the same intensity as the first oxidation process. This second oxidation process, however, is not chemically reversible. Furthermore, a bulk electrolysis experiment, carried out at a constant potential of $0.7 \mathrm{~V}$ versus SCE, resulted in

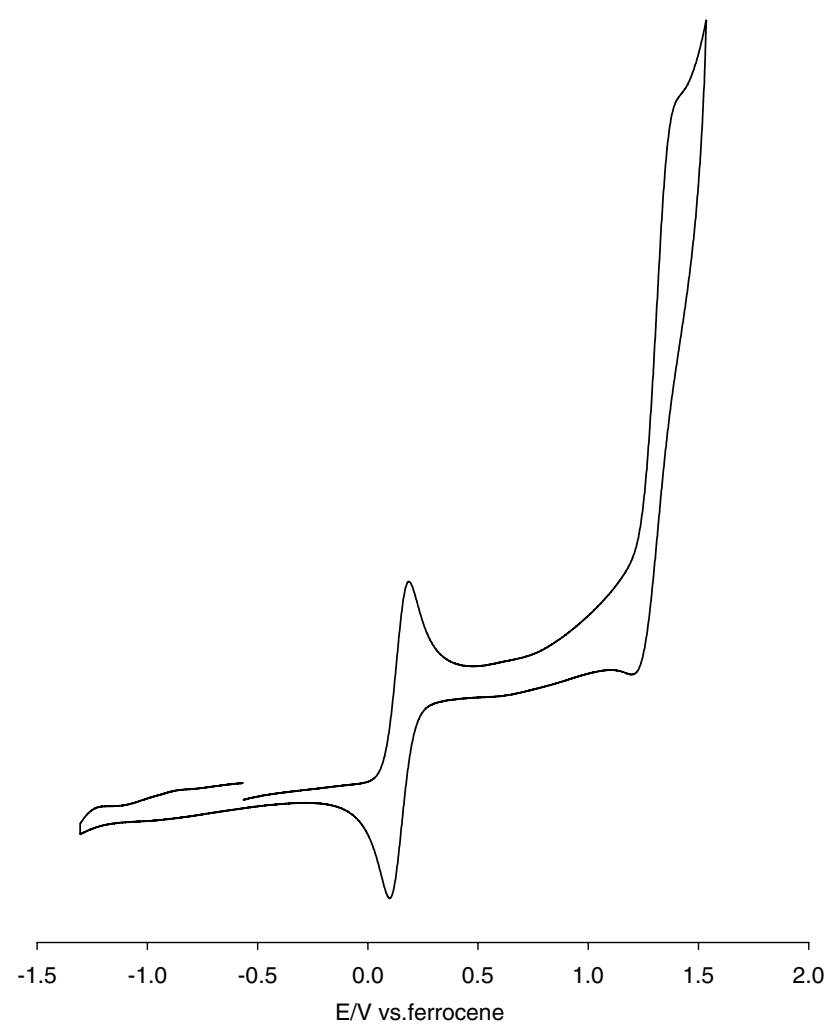

Fig. 2. Cyclic voltammogram of compound $[\mathrm{Tp} * \mathrm{Mo}(\mathrm{O}) \mathrm{Cl}](\mu-$ O) $\left[\mathrm{Tp} * \mathrm{Mo}\left(\mathrm{NC}_{6} \mathrm{H}_{4} \mathrm{OCl}-4\right) \mathrm{Cl}\right]$ in $\mathrm{CH}_{2} \mathrm{Cl}_{2}$ solution. Scan rate $=100 \mathrm{mV} \mathrm{s}^{-1}$. the consumption of slightly less than one electron per dinuclear unit. A subsequent cyclic voltammogram of the electrolyzed solution exhibited the same reversible wave at $E_{1 / 2}=+0.14 \mathrm{~V}$ as a reductive process, demonstrating the chemical stability of the oxidized species. Finally, the resulting oxidized solution was investigated by EPR spectroscopy. It shows a sharp resonance with Mo satellites $\left(g=1.950 ; a_{\mathrm{Mo}}=35.8 \mathrm{G}\right)$, which is characteristic of coupling of the unpaired electron with a single Mo atom. This indicates that the unpaired electron in the oxidized species is mostly localized on one of the two Mo centers.

When considering only the inductive effect expected for the introduction of the aryl substituent, the oxidation potential is expected to become more positive upon introduction of the more electronegative ligand. However, on going from the I substituent to the much more electronegative $\mathrm{F}$ substituent on the aryl meta position (which does not transmit mesomeric effects), the potential remains practically unchanged. This means that the aryl meta position is already too far from the dimetal core to significantly affect the metal electron density. Thus, any effect observed upon substitution at the para position, which is even further from the dimetal unit, must be attributed to a mesomeric effect. The marginally less positive $E_{1 / 2}$ for the oxidation process of the $p-\mathrm{Cl}$ derivative relative to the $p-\mathrm{Br}$ derivative could then be attributed to the slightly greater $+\mathrm{M}$ effect of the $\mathrm{Cl}$ substituent. The alkoxide substituents have a greater effect, since the potential shifts by $-0.08 \mathrm{~V}$ relative to the $p-\mathrm{Cl}$ compound. The three OR groups have an identical effect.

The cyclic voltammogram of the symmetric oxo compound $\mathbf{9}$, on the other hand, is significantly different, see Fig. 3. It consists of a reversible oxidation process at a higher potential relative to the oxo-imido species analyzed above $\left(E_{1 / 2}=0.53 \mathrm{~V}\right)$, and a partially chemically reversible reduction process with $E_{1 / 2}=$ $-1.49 \mathrm{~V}$. The intensity of the two cathodic peaks is

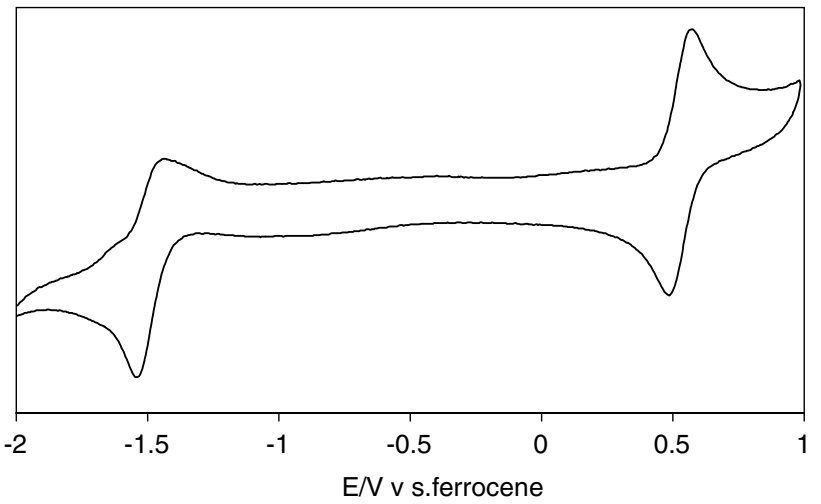

Fig. 3. Cyclic voltammogram of compound $\left[\mathrm{Tp} * \mathrm{Mo}(\mathrm{O}) \mathrm{Cl}_{2}(\mu-\mathrm{O})(\mathbf{9})\right.$ in $\mathrm{CH}_{2} \mathrm{Cl}_{2}$ solution. Scan rate $=100 \mathrm{mV} \mathrm{s}^{-1}$. 
identical, indicating that the two processes involve the same number of electrons. These are again most likely one-electron processes, because of the peak-to-peak separations of 90 and $120 \mathrm{mV}$ for the oxidation and reduction processes, respectively, versus a value of $145 \mathrm{mV}$ for the ferrocene standard added to the same solution. Consequently, the replacement of one oxo ligand with the imido ligand has a dramatic effect on the electron density of the redox-active dimetal unit: the imido ligand shifts the oxidation potential negatively by ca. $0.4 \mathrm{~V}$, and the reduction potential is correspondingly shifted negatively, beyond the solvent discharge. This is consistent with the greater electron-releasing power of the amido functionality.

\section{Conclusion}

In this study, the oxo-imido $\mathrm{Mo}(\mathrm{V})$ compounds $[\mathrm{Tp} * \mathrm{Mo}(\mathrm{O}) \mathrm{Cl}](\mu-\mathrm{O})[\mathrm{Tp} * \mathrm{Mo}(\mathrm{NAr}) \mathrm{Cl}] \quad\left(\mathrm{Ar}=\mathrm{C}_{6} \mathrm{H}_{4} \mathrm{OEt}-\right.$ $\left.4, \mathrm{C}_{6} \mathrm{H}_{4} \mathrm{OPr}^{n}-4\right)$ were prepared by the reaction of [MoTp* $(\mathrm{O}) \mathrm{Cl}_{2}$ ] with $\mathrm{H}_{2} \mathrm{NC}_{6} \mathrm{H}_{4} \mathrm{R}-4 \quad(\mathrm{R}=\mathrm{OEt} ; \mathrm{OPr})$. Spectroscopic characterization of these species confirmed that they have the same structure previously established for other related oxo-imido $\mathrm{Mo}(\mathrm{V})$ dimers. The formation of these species could be explained by the greater Lewis basicity of the amido-substituted intermediate and the greater Lewis acidity of the dichloride starting complex. Another interesting feature is the formation of the dinuclear $\mu$-oxomolybdenum(V) compound, $[\mathrm{Tp} * \mathrm{Mo}(\mathrm{O}) \mathrm{Cl}]_{2}(\mu-\mathrm{O})$, from $\left[\mathrm{MoTp}^{*}(\mathrm{O}) \mathrm{Cl}_{2}\right]$ and $\mathrm{C}_{6} \mathrm{H}_{5} \mathrm{NH}_{2}$ as the major product whereas it is a by-product of the related reactions with the substituted anilines. Electrochemical studies were performed on the entire family of compounds in comparison with the electrochemical behavior of the related compound $\left[\mathrm{Tp}^{*} \mathrm{Mo}(\mathrm{O}) \mathrm{Cl}\right]_{2}(\mu-\mathrm{O})$. It was observed that all the mixed oxo-imido compounds displayed a reversible oxidation process and no further oxidation process nor any reduction process down to the potential at which the $\mathrm{CH}_{2} \mathrm{Cl}_{2}$ starts to discharge. On the other hand, the cyclic voltammogram of the symmetric oxo compound, $[\mathrm{Tp} * \mathrm{Mo}(\mathrm{O}) \mathrm{Cl}]_{2}(\mu-\mathrm{O})$, showed a reversible oxidation process at higher potential relative to the oxo-imido species and a partially chemically reversible reduction process. The replacement of one oxo ligand with the imido ligand has a much greater effect on the electron density of the redox-active dimetal unit than changing the nature of the aryl group substituent.

\section{Acknowledgments}

We are thankful to the Research Foundation of "Izmir Institute of Technology" and TUBITAK, Research Council of Turkey, for financial support and Professor
J.A. McCleverty for providing the Tp* (hydrotris(3,5-dimethyl-1-pyrazolyl)borate) ligand. R.P. thanks CNRS for support.

\section{References}

[1] S. Trofimenko, J. Am. Chem. Soc. 89 (1967) 3170.

[2] S. Trofimenko, J.P. Jesson, D.R. Eaton, J. Am. Chem. Soc. 89 (1967) 3148.

[3] D.E. Wigley, Prog. Inorg. Chem. 42 (1994) 239.

[4] W.A. Nugent, J.M. Mayer, Metal-ligand multiple bonds, Wiley, New York, 1988.

[5] W.D. Philip, V.C. Gibson, W. Clegg, J. Chem. Soc., Dalton Trans. (1995) 3313.

[6] G.L. Casty, T.D. Tilley, G.P.A. Yap, A.L. Rheingold, Organometallics 16 (1997) 4746.

[7] V.C. Gibson, C. Redshaw, G.L.P. Walker, J.A.K. Howard, V.J. Hoy, J.M. Cole, L.G. Kuzmina, D.S. De Silva, J. Chem. Soc., Dalton Trans. (1999) 161.

[8] J.A.M. Brandts, M.V. Leur, R.A. Gossage, J. Boersma, A.L. Spek, G. van Koten, Organometallics 18 (1999) 2633.

[9] P.J.A.M. Brandts, J. Boersma, A.L. Spek, G. van Koten, Eur. J. Inorg. Chem. (1999) 1727.

[10] M.C.W. Chan, F.W. Lee, K.K. Cheung, C.M. Che, J. Chem. Soc., Dalton Trans. (1999) 3197.

[11] S.M. Lee, R. Kowallick, M. Marcaccio, J.A. McCleverty, M.D. Ward, J. Chem. Soc., Dalton Trans. (1998) 3443.

[12] F. Montilla, A. Pastor, A. Galindo, J. Organomet. Chem. 590 (1999) 202.

[13] W.M. Vaughan, K.A. Abboud, J.M. Boncella, J. Organomet. Chem. 485 (1995) 37.

[14] V.C. Gibson, C. Redshaw, W. Clegg, M.R.J. Elsegood, J. Chem. Soc., Dalton Trans. (1997) 3207.

[15] J. Sundermeyer, J. Putterlik, M. Foth, J.S. Field, N. Ramesar, Chem. Ber. 127 (1994) 1201.

[16] S. Scheuer, J. Fischer, J. Kress, Organometallics 14 (1995) 2627.

[17] W.M. Vaughan, K.A. Abboud, J.M. Boncella, J. Organomet. Chem. 485 (1995) 37.

[18] J.M. Boncella, M.L. Cajigal, A.S. Gamble, K.H. Abboud, Polyhedron 15 (1996) 2071.

[19] A. Galindo, F. Montilla, A. Pastor, E. Carmona, E. GutierrezPuebla, A. Monge, C. Ruiz, Inorg. Chem. 36 (1997) 2379.

[20] V.C. Gibson, C. Redshaw, W. Clegg, M.R.J. Elsegood, U. Siemeling, T. Turk, Polyhedron 23 (2004) 189.

[21] F. Montilla, A. Pastor, A. Galindo, J. Organomet. Chem. 590 (1999) 202.

[22] A.A. Danopoulos, G. Wilkinson, B.H. Bates, M.B. Hursthouse, J. Chem. Soc., Dalton Trans. (1991) 269.

[23] A.A. Danopoulos, G. Wilkinson, T.K.N. Sweet, M.B. Hursthouse, Polyhedron 15 (1996) 873.

[24] A.A. Danopoulos, G. Wilkinson, D.J. Williams, J. Chem. Soc., Chem. Commun. (1991) 181.

[25] V.C. Gibson, C. Redshaw, G.L.P. Walker, W. Clegg, M.R.J. Elsegood, J. Organomet. Chem. 689 (2004) 332.

[26] V.C. Gibson, A.J. Graham, D.L. Ormsby, B.P. Ward, A.J.P. White, D.J. Williams, J. Chem. Soc., Dalton Trans. (2002) 2597.

[27] I. Topaloglu-Sozuer, A. Gunyar, J.C. Jeffery, H. Hamidov, Trans. Met. Chem. 29 (2004) 780.

[28] I. Topaloglu-Sozuer, S.D. Irdem, J.C. Jeffery, H. Hamidov, O.S. Senturk, Z. Naturforsch 60b (2005) 15.

[29] I. Topaloglu-Sozuer, S.D. Irdem, J.C. Jeffery, H. Hamidov, J. Coord. Chem. 58 (2) (2005) 175.

[30] M.B. Kassim, R.L. Paul, J.C. Jeffery, J.A. McCleverty, M.D. Ward, Inorg. Chim. Acta 327 (2002) 160. 
[31] A. Miller, C. Doonan, L. Laughlin, E.R.T. Tiekink, C. Young, Inorg. Chim. Acta 337 (2002) 393

[32] S.A. Roberts, C.G. Young, C.A. Kippe, J.W.E. Cleland, K. Yamanouchi, M.D. Carducci, J.H. Enemark, Inorg. Chem. 29 (1990) 3650.
[33] K. Dehnicke, J. Strähle, Angew. Chem., Int. Ed. Engl. 20 (1981) 413.

[34] K. Nakamoto, Infrared and Raman Spectra of Inorganic and Coordination Compounds, 4th ed., Wiley, New York, 1986. 